\title{
Antimicrobial treatment of community acquired pneumonia in adults: A conference report
}

\begin{abstract}
THE CANADIAN COMMUNITY ACQUIRED PNE
OMMUNITy ACQUIRED PNEUMONIA REPRESENTS A major medical problem. This is despite advances in our understanding of the etiology, epidemiology and pathogenesis of the disease as well as the availability of numerous types of antimicrobials. For those cases requiring admission to hospital, the overall mortality rate can exceed $20 \%$ (1).

Since community acquired pneumonia is not a reportable disease, it is difficult to obtain accurate statistics on its true incidence. Figures from the United States suggest that approximately 3.3 million cases occur annually in ambulatory patients. Data from England support an incidence of one to three cases of pneumonia per 1000 adults per year while in Sweden, the incidence is five per 1000 . To complicate matters further, it is often difficult to identify the etiological pathogen. Pneumonia and influenza are among the leading causes of death in Americans aged 65 years or older (2).
\end{abstract}

\section{DEVELOPMENT OF GUIDELINES}

In order to develop a standardized approach to the antimicrobial treatment of community acquired pneumonia in Canada, a meeting was held in Halifax, Nova Scotia in November 1991. The participants were physicians with a variety of backgrounds including family practice, infectious diseases, microbiology and respirology. Experts from Canada, the United States, England and Sweden attended, all with a particular interest in respiratory tract infections. The guidelines presented in this paper are a representation of the opinions of these experts.

These guidelines were developed solely to help in the initial antimicrobial management of patients with community acquired pneumonia. They are neither definitive nor all encompassing but are meant solely to provide the practising physician with a rational approach to the initial treatment of community acquired pneumonia and are based upon careful consideration of etiological and epidemiological factors and, above all, the safety and welfare of the patient. Whenever possible, attempts should be made to establish a precise etiological diagnosis. In cases where a specific pathogen is identified, therapy may be specifically targeted using an antimicrobial with a relatively narrow spectrum of activity to which the organism is sensitive. In choosing any antimicrobial, once issues of efficacy and toxicity have been addressed, cost should then be considered.

In developing these guidelines, it was felt that to be workable they must be kept as practical and as simple as possible. Trying to encompass every eventuality would lead to overly complex guidelines that ultimately would be discarded. Accordingly, we have chosen not to deal with the issue of tuberculosis or with high risk patients, such as those with human immunodeficiency virus infection, neoplastic disease

Chairmen of Working Groups: Dr LA Mandell, Dr T Marrie, Dr V Yu

Other participants: Dr M Fleming, Dr K Forward, Dr R Gleckman, Dr R Gold, Dr M Gribble, Dr R Grossman, Dr J MacFarlane,

Dr LE Nicolle, Dr M Niederman, Dr A Ortquist, Dr G Sarosi, Dr W Schlech, Dr P Turgeon, Dr A Verghese, Dr M White

The Consensus Conference was supported by an educational grant from Glaxo Canada Inc

Correspondence and reprints: Dr Lionel A Mandell, McMaster Medical Unit, Henderson General Hospital, 711 Concession Street,

Hamilton, Ontario L8V 1C3. Telephone (905) 574-8520, Fax (905) 575-7320

Reproduced from Can J Infect Dis 1993;4:25-8 
TABLE 1

Treatment options for community acquired pneumonia

Clinical presentation - not severe

Treatment - as outpatient oral therapy or inpatient therapy

\begin{tabular}{|c|c|c|c|}
\hline & Patient previously well and/or $<65$ years old & Comorbid illness and/or $>65$ years old & \\
\hline Organisms & $\begin{array}{l}\text { Streptococcus pneumoniae } \\
\text { Mycoplasma pneumoniae } \\
\text { Chlamydia pneumoniae } \\
\text { Haemophilus influenzae }\end{array}$ & $\begin{array}{l}\text { S pneumoniae } \\
\text { H influenzae } \\
\text { Oral anaerobes } \\
\text { Gram-negative rods } \\
\text { Staphylococcus aureus } \\
\text { Legionella species }\end{array}$ & \\
\hline Drugs & $\begin{array}{l}\text { 1. Macrolide } \\
\text { 2. Tetracycline* }\end{array}$ & $\begin{array}{l}\text { 1. Second generation cephalosporin } \\
\text { 2. Trimethoprim-sulfamethoxazole } \\
\text { 3. Penicillin plus beta-lactamase inhibitor }\end{array}$ & \pm macrolide $^{\dagger}$ \\
\hline
\end{tabular}

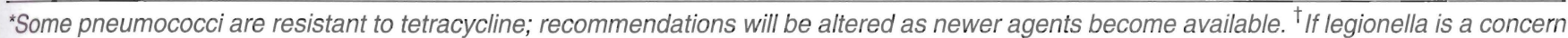

TABLE 2

Treatment options for community acquired pneumonia

Clinical presentation - severe

Treatment - in hospital

\begin{tabular}{|c|c|c|c|c|}
\hline & \multicolumn{2}{|c|}{ Hospital ward } & \multicolumn{2}{|c|}{ Intensive care unit } \\
\hline & No comorbidity & Comorbidity & No comorbidity & Comorbidity \\
\hline Organisms & $\begin{array}{l}\text { Streptococcus pneumoniae } \\
\text { Legionella species } \\
\text { Haemophilus influenzae } \\
\text { Mycoplasma pneumoniae } \\
\text { Staphylococcus aureus } \\
\text { Chlamydia pneumoniae }\end{array}$ & $\begin{array}{l}\text { S pneumoniae } \\
\text { H influenzae } \\
\text { Gram-negative rods } \\
\text { Oral anaerobes } \\
\text { Legionella species } \\
\text { S aureus }\end{array}$ & $\begin{array}{l}\text { S pneumoniae } \\
\text { Legionella species } \\
\text { H influenzae } \\
\text { Gram-negative rods } \\
\text { (including Pseudomonas } \text { Peruginosa*) } \\
\text { M pneumoniae } \\
S \text { aureus } \\
\text { C pneumoniae }\end{array}$ & $\begin{array}{l}S \text { pneumoniae } \\
H \text { influenzae } \\
\text { Gram-negative rods } \\
\text { (including } P \text { aeruginosa*) }^{*} \text { Legionella species } \\
S \text { aureus }\end{array}$ \\
\hline Drugs & \multicolumn{2}{|c|}{$\begin{array}{l}\text { Second or third generation cephalosporin } \\
\pm \text { macrolide } \pm \text { rifampin } \\
\text { In penicillin-allergic patients - } \\
\text { trimethoprim-sulfamethoxazole plus macrolide }\end{array}$} & \multicolumn{2}{|c|}{$\begin{array}{l}\text { Macrolide } \pm \text { rifampin } \\
\text { plus third generation cephalosporin with } \\
\text { antipseudomonas activity } \\
\text { or imipenem/cilastatin } \\
\text { or ciprofloxacin }\end{array}$} \\
\hline
\end{tabular}

"Due to the high mortality associated with $\mathrm{P}$ aeruginosa, an aminoglycoside should be added at least for the first few days, whether one uses a third generation cephalosporin, imipenem or ciprofloxacin. ${ }^{\dagger}$ First-line cover for $\mathrm{S}$ aureus (oxacillin-sensitive) is a penicillinase-resistant semisynthetic penicillin; however, the regimens listed above, while not optimal, would provide reasonable cover until identification and sensitivities of the pathogens were determined, at which time therapy may be altered

or immunosuppressed patients. Such patients generally tend to be managed by physicians with specific expertise in these areas. Since insufficient data exist on the true incidence of viral causes of community acquired pneumonia, we have excluded viruses from these guidelines.

\section{APPROACH TO PNEUMONIA}

Although a variety of classifications of pneumonia exist, we have chosen to base our approach to treatment upon the following four variables:

- The severity of illness upon clinical presentation;

- Whether the pneumonia was acquired in the community setting itself or in a nursing home;

- The presence or absence of comorbid illness (or age older than 65 years);

- Whether treatment is to be given in the community setting, the nursing home or following admission of the patient to a hospital.
While an absolute definition of severity of illness is not possible, some general guidelines can be provided. Criteria for 'severe pneumonia' include patients presenting with any of the following: respiratory failure $\left(\mathrm{PaO}_{2}<60 \mathrm{mmHg}\right.$ [with the exception of patients with chronic obstructive lung disease who may be hypoxemic without pneumonia]); respiratory rate more than 30/min; sepsis with evidence of end organ dysfunction; extrapulmonary septic complications; cavitation or involvement of more than one lobe on chest radiograph (3-5).

Comorbid illness is defined as chronic obstructive lung disease, diabetes mellitus, renal insufficiency, congestive heart failure or recent hospitalization within one year of the presentation with pneumonia (6). Other medical conditions may also exist that might be construed as comorbid conditions. The attending physician's clinical judgement should be used in assessing such cases.

An approach which incorporates these factors allowed 
TABLE 3

Treatment options for nursing home acquired pneumonia Clinical presentation - not severe

Treatment - in nursing home

\begin{tabular}{ll}
\hline & Comorbid illness and/or $>65$ years \\
\hline Organisms & $\begin{array}{l}\text { Streptococcus pneumoniae } \\
\text { Haemophilus influenzae } \\
\text { Oral anaerobes } \\
\text { Gram-negative rods } \\
\text { Staphylococcus aureus } \\
\text { Legionella species } \\
\text { Drugs }\end{array}$ \\
& $\begin{array}{l}\text { 1. Second generation } \\
\text { cephalosporin }\end{array}$ \\
& $\begin{array}{l}\text { 2. Trimethoprim-sulfa- } \\
\text { methoxazole }\end{array}$ \\
& 3. Amoxicillin-clavulanic acid
\end{tabular}

*If legionella is a concern

TABLE 4

Treatment options for nursing home acquired pneumonia Clinical presentation - severe

Treatment - in nursing home*

\begin{tabular}{ll}
\hline & Nursing home \\
\hline Organisms & Streptococcus pneumoniae \\
& Haemophilus influenzae \\
& Oral anaerobes \\
& Gram-negative rods \\
& Staphylococcus aureus \\
& Legionella species \\
& Penicillin plus ciprofloxacin (oral) \\
Drugs & or second generation cephalosporin \\
& \pm macrolide (oral) \\
& or ceftriaxone (intramuscular) \\
& \pm macrolide (oral) \\
& In penicillin-allergic patients \\
& Ciprofloxacin plus clindamycin (intramuscular)
\end{tabular}

*If patient is to be transferred to hospital for treatment, see Table 2

consideration of the greatest number of variables that might impact upon the treatment as well as the prognosis of the individual patient. We specifically avoided the use of a syndrome approach since there can be considerable overlap in clinical symptoms and physical signs, especially in the elderly (7). These guidelines presuppose that in all cases, the individual physician dealing with the patient is the best judge of what to do. In all cases, knowledge of local epidemiology and resistance patterns should be used to modify these guidelines where appropriate.

Based upon the variables mentioned above, the various treatment options are presented in Tables 1, 2, 3 and 4. We have tried to use classes of drugs rather than individual agents whenever possible. However, if only one drug in a given class is available or felt to be suitable, then a specific drug name has been used. Tables 1 and 2 deal with patients who have acquired pneumonia in the community setting and who present with clinical pictures that are not severe and severe, respectively. Tables 3 and 4 deal with patients with nursing home acquired pneumonia which are not severe and severe, respectively. The practice of transferring patients

\section{APPENDIX}

Drug class

I. Beta-lactams

a) Penicillins

b) Penicillins plus

beta-lactamase

inhibitors

c) Cephalosporins

Second generation

Third generation

Third generation with anti-pseudomonas activity

d) Carbapenem

II. Macrolides

III. Lincosamides

IV. Fluoroquinolones

V. Aminoglycosides

VI. Rifamycins

VII. Tetracyclines

VIII. Miscellaneous

Individual agents

Penicillin G

Phenoxymethyl penicillin

Amoxicillin-clavulanic acid (oral)

Ticarcillin/clavulanic acid (iv)

Cefuroxime

Cefamandol

Ceftriaxone

Cefotaxime

Ceftazidime

Cefoperazone $^{*}$

Imipenem/cilastatin

Erythromycin

Clarithromycin

Clindamycin

Ciprofloxacin

Ofloxacin*

Gentamicin

Tobramycin

Rifampin

Tetracycline

Trimethoprim-

sulfamethoxazole

*Less active against Pseudomonas aeruginosa than other drug in its class

from a nursing home to a hospital depends upon a variety of social and economic factors and varies from province to province within Canada and from country to country outside Canada.

Most patients with community acquired pneumonia do not need to be admitted to hospital. Of those that do require admission, not all are necessarily severely ill. Of the four tables, Table 1 perhaps applies to the largest percentage of patients.

For patients admitted to hospital, close follow-up is assured but for patients treated at home, follow-up at two to three days is important. In all cases, whenever additional information, such as culture and sensitivity data, which may impact treatment comes to light, the responsible physician should make any necessary modifications or adjustments to the initial treatment regimen.

There is no single approach to the diagnosis and treatment of pneumonia that will suffice under all circumstances. What we are using here is an approach that allows for the initial selection of empiric antimicrobial therapy.

While penicillin is the drug of choice for infection caused by sensitive strains of Streptococcus pneumoniae, it does not provide cover for pathogens such as Mycoplasma pneumoniae, Legionella pneumophila and Chlamydia pneumoniae. Erythromycin, which has excellent activity against the latter three pathogens, is essentially ineffective against Haemophilus influenzae. To confound the situation further, betalactamase production by $H$ influenzae and Moraxella catarrhalis makes routine use of ampicillin or amoxicillin unwise (8). Obviously, if a proper sputum sample shows 
many polymorphonuclear leukocytes and Gram-positive diplococci on Gram stain, penicillin would be the agent of choice. In many situations, however, the decisions are not as clear cut and it is for such situations that these guidelines are intended. As newer antimicrobials become available or as the epidemiology of responsible pathogens changes, these guidelines will be updated.

At present it is recommended that the diagnostic work-up of a patient with known or suspected pneumonia include a careful history, including identification of any comorbid conditions, and a thorough physical examination.

\section{REFERENCES}

1. Marrie TJ, Durant R, Yates L. Community-acquired pneumonia requiring hospitalization: 5-year prospective study. Rev Infect Dis 1989:11:586-99.

2. Hospitalizations for the leading causes of death among the elderly - US, 1987. MMWR 1990;39:777.

3. Pachon J, Prados D, Capote F, Cuello JA, Garnacho J, Verano A. Severe community-acquired pneumonia. Etiology, prognosis, and treatment. Am Rev Resp Dis 1990;142:369-73.

4. Farr BM, Sloman AJ, Fisch MJ. Predicting death in patients hospitalized for community-acquired pneumonia. Ann Intern Med 1991;115:428-36.

5. Torres A, Serra-Batlles J, Ferrer A, et al. Severe community-acquired pneumonia.Epidemiology and prognostic
One should also attempt to obtain a proper sputum sample for Gram stain and culture as well as blood samples for a white blood cell count and differential, serology (Legionella species, $M$ pneumoniae, $C$ pneumoniae) and a posteroanterior and lateral chest radiograph (9). Blood cultures should also be taken routinely from patients who are to be admitted to hospital.

In all cases, consideration must also be given to ancillary modes of treatment where appropriate, including respiratory support, positioning of the patient and management of complications.

factors. Am Rev Resp Dis 1991;144:312-8.

6. Fine MJ, Smith DN, Singer DE. Hospitalization decision in patients with community-acquired pneumonia: A prospective cohort study. Am J Med 1990;89:713-21.

7. Fang G-D, Fine M, Orloff J, et al.New and emerging etiologies for community-acquired pneumonia with implications for therapy. A prospective multicenter study of 359 cases. Medicine 1990;69:307-16.

8. Tremblay LD, L'Ecuyer J, Provencher P, Bergeron M, Canadian Study Group. Susceptibility of Haemophilus influenzae to antimicrobial agents used in Canada. Can Med Assoc J 1990;143:895-901.

9. Gerding DN, ed. Diagnosis of Pneumonia. Semin Respir Infect 1988;111:81-178. 


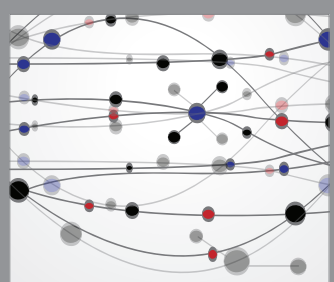

The Scientific World Journal
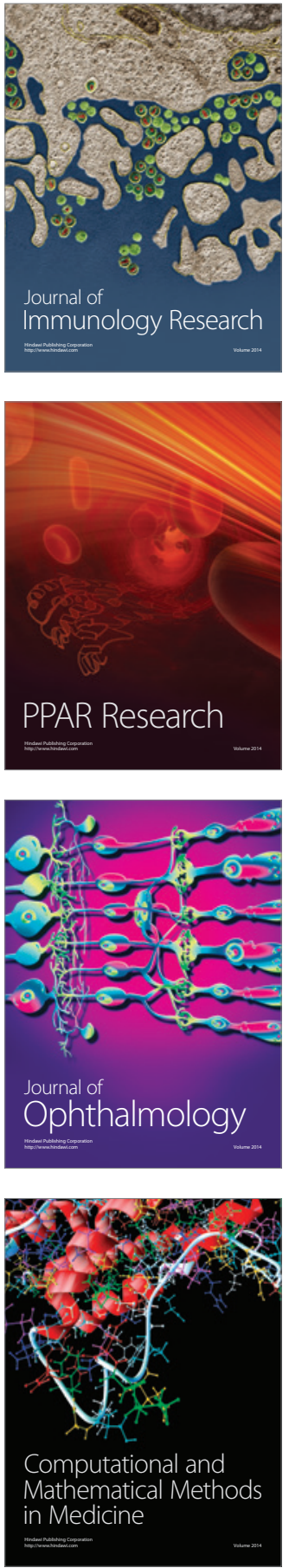

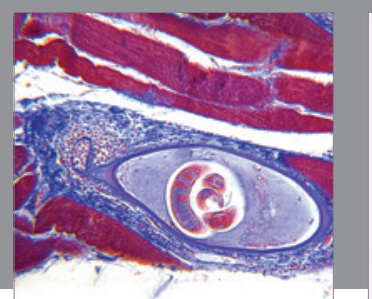

Gastroenterology Research and Practice

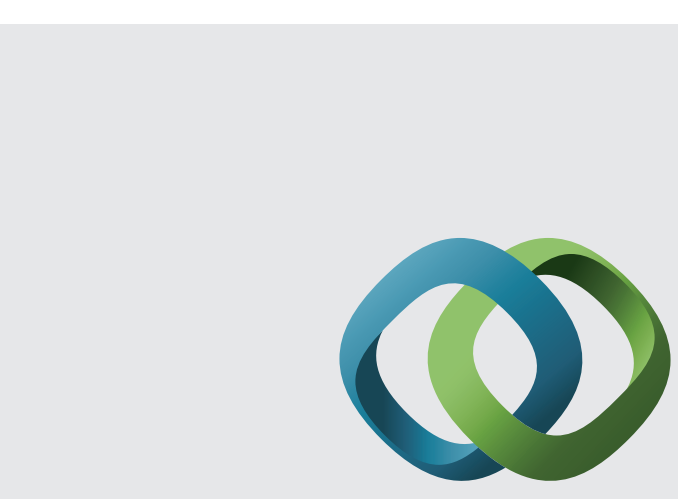

\section{Hindawi}

Submit your manuscripts at

http://www.hindawi.com
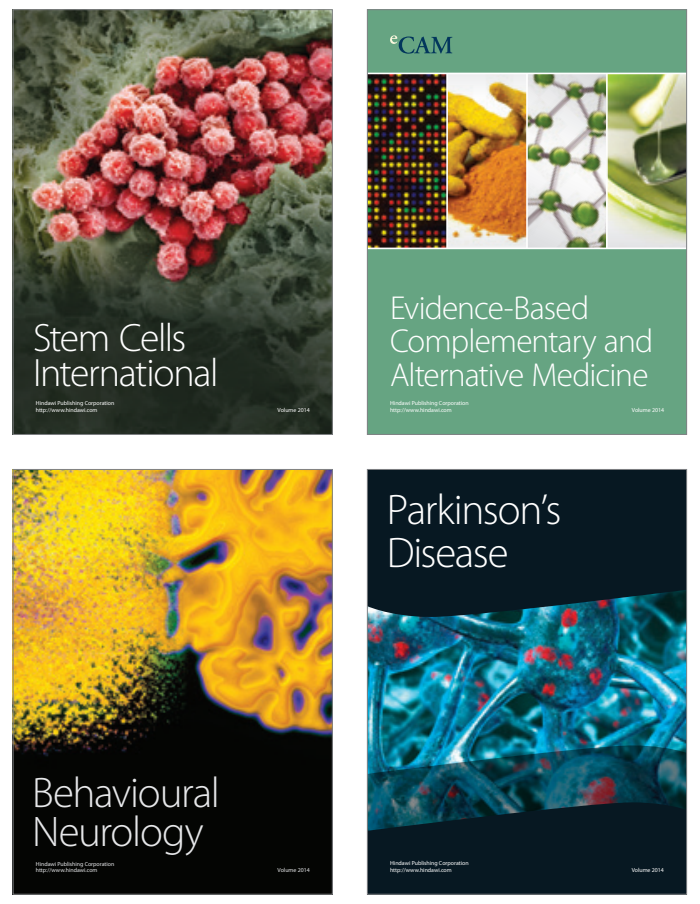
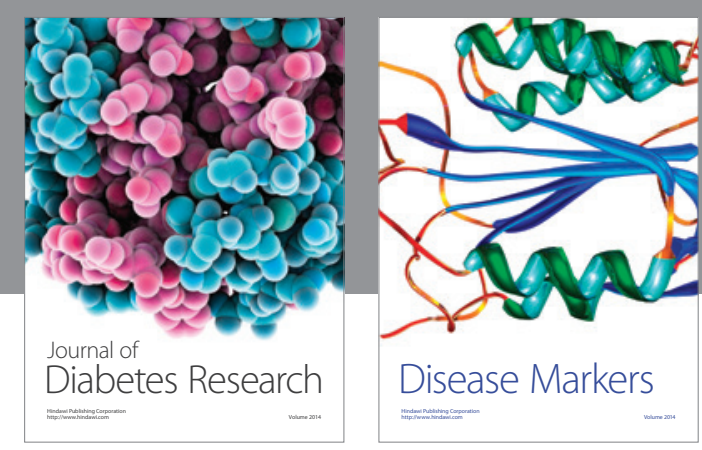

Disease Markers
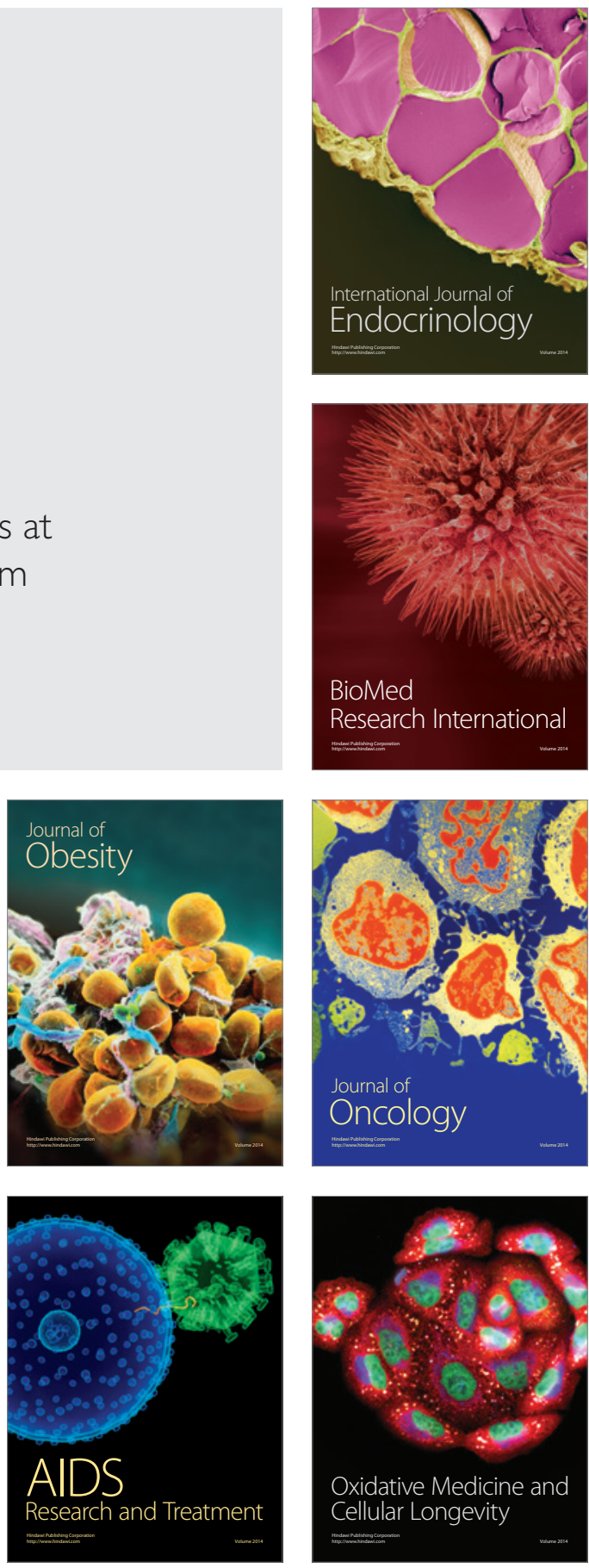